\title{
HISTÓRIA REGIONAL E LOCAL: o que dizem os professores e os estudantes?
}

\author{
Shirley Cláudia da Silva e Souza* \\ Renilson Rosa Ribeiro**
}

\begin{abstract}
RESUMO: O artigo apresenta resultados de pesquisa desenvolvida com narrativas de professores de História e estudantes do Ensino Médio de escolas públicas estaduais da cidade de Cáceres, acerca do ensino de história regional e local. Dedicamos especial atenção à análise da abordagem da História Regional e Local a partir dos estudantes de duas escolas, identificadas como Escola A e Escola B, sem hierarquizar as unidades escolares e seus sujeitos. A pesquisa empírica foi desenvolvida entre março e novembro de 2017, a partir de questionários com questões abertas e fechadas sobre o que os sujeitos conheciam sobre a história de Cáceres e Mato Grosso. Podemos destacar nas análises das narrativas que as formas institucionais e culturais da História de Mato Grosso e de Cáceres privilegiam acontecimentos históricos ancorados no discurso econômico tomando como referência a região Sudeste do Brasil.
\end{abstract}

PALAVRAS-CHAVE: História regional; História local; Ensino Médio; Cáceres-Mato Grosso.

\section{Regional and local history: what do teachers and students say?}

ABSTRACT: The article presents results of research developed with narratives from History teachers and high school students from state public schools in the city of Cáceres, about the teaching of regional and local history. The municipality of Cáceres is located in the southwest of Mato Grosso, integrating the micro-region of the upper Pantanal and the mesoregion of the center-south of Mato Grosso. We pay special attention to the analysis of the approach of Regional and Local History from students from two schools, identified as School I and School II, without ranking the school units and their subjects. The empirical research was carried out between march and November 2017, and took as an interest the intersection of narratives that gain relevance when we approach them with investigations that also focused on narratives of other young students.

KEYWORDS: Regional history; Local history; High school; Cáceres-Mato Grosso.

\section{Historia regional y local: ¿qué dicen profesores y alumnos?}

RESUMEN: El artículo presenta resultados de una investigación desarrollada con narrativas de profesores de Historia y estudiantes de secundaria de los colegios públicos estatales de la ciudad de Cáceres sobre la enseñanza de la historia regional y local. El municipio de Cáceres, se ubica en el suroeste de Mato Grosso, integrando la microrregión del Alto Pantanal y la mesoregión del centro-sur de Mato Grosso. Prestamos especial atención al análisis del enfoque de Historia Regional y Local de los estudiantes de dos escuelas, identificadas como Escuela I y Escuela II, sin jerarquizar las unidades escolares y sus materias. La investigación empírica se realizó entre marzo y noviembre de 2017, y tomó como interés la intersección de narrativas que cobran relevancia cuando las abordamos con investigaciones que también se enfocaron en narrativas de otros jóvenes estudiantes.

PALABRAS CLAVE: Historia regional; Historia local; Escuela secundaria; Cáceres-Mato Grosso.

\footnotetext{
* Mestra em História e doutoranda em Educação pela Universidade Federal de Mato Grosso. Bolsista Capes. Contato: Universidade Federal de Mato Grosso. Av. Fernando Corrêa da Costa, n. 2.367, Bairro Boa Esperança, Cep: 78.060900, Cuiabá-MT, Brasil. E-mail: shirley-hisjor@ hotmail.com. ORCID: https://orcid.org/0000-0003-3932-8655

**Doutor em História pela Universidade Estadual de Campinas. Atualmente é Professor associado do Departamento de História e do ProfHistória - Mestrado Profissional em Ensino de História na Universidade Federal de Mato Grosso. Contato: Universidade Federal de Mato Grosso. Av. Fernando Corrêa da Costa, n. 2.367, Bairro Boa Esperança, Cep: 78.060-900, Cuiabá/MT, Brasil. E-mail: rrrenilson@yahoo.com. ORCID: https://orcid.org/0000-0002-2809-1376
} 
O ensino de conteúdos desvinculados do cotidiano e do contexto no qual os estudantes estão inseridos tem sido apontado como um dos fatores que tem levado ao abandono da escola, como também causa do desinteresse pelas disciplinas escolares. A História Regional e Local tem se apresentado como alternativa à História Global por se tratar do recorte que está mais próximo dos sujeitos nele inserido, enlaçando suas experiências e os colocando dentro do debate histórico para além do econômico e político privilegiando, assim, o antropológico e cultural. (Souza, 2019). ${ }^{1}$

O município de Cáceres está situado a sudoeste de Mato Grosso, integrando a microrregião do alto Pantanal e a mesorregião do centro-sul mato-grossenses. Dedicamos nos limites deste artigo especial atenção à análise da abordagem da História Regional e Local a partir dos estudantes de duas escolas, identificadas como Escola A e Escola B, sem hierarquizar as unidades escolares e seus sujeitos. A pesquisa empírica foi desenvolvida entre março e novembro de 2017 e assumiu como interesse o cruzamento das narrativas de professores e estudantes da educação básica para compreendermos o que sabem sobre a história de Mato Grosso.

Com base nas narrativas dos estudantes, somadas às historiográficas regionais - isto é, a cada espacialidade/temporalidade capturada sobre a história de Mato Grosso e de Cáceres apresentamos recortes de pesquisas de historiadores e pesquisadores que adotam como cenário a história regional e local. Isto se dá com vistas a enriquecer as narrativas, bem como pôr em destaque a produção historiográfica em expansão, levando-se em conta que as universidades produzem muito material diversificado sobre os temas.

A realização dos questionários foi possível graças ao apoio dos professores das respectivas escolas. Adotamos o critério de que este roteiro fosse respondido, exclusivamente, em sala de aula para que, assim, evitássemos que os estudantes recorressem às pesquisas rápidas via Internet sobre perguntas específicas como, por exemplo, "O que você sabe sobre história de Mato Grosso e sobre a História de Cáceres?” Assim, proporcionou-se a obtenção de respostas espontâneas sobre o conhecimento aprendido ao longo de suas vidas escolares.

Após a análise da história do Ensino de História no Brasil, com destaque para as questões curriculares, dos projetos pedagógicos das escolas e dos planos de ensino/aula, nossas reflexões se voltam para a compreensão de como os professores entendem o lugar da história regional e local em suas aulas. Não obstante, analisamos as formas como os estudantes aprendem ou percebem essas temáticas ao longo da sua formação no Ensino Médio. 
Chegamos ao resultado de que, o ensino de História tem buscado e encontrado na educação muitos de seus referenciais, consolidando certa tradição na pesquisa que vem sendo desenvolvida, desde a década de 1980, dialogando potencialmente com narrativas dos sujeitos que estão inseridos na escola. Além disso, o ensino de História Regional e Local contribui para fortalecer os conhecimentos acerca do mundo em que estes sujeitos estão inseridos, fazendo-os refletirem sobre ele, criticá-lo e buscar transformá-lo.

\section{O que dizem os professores de História? ${ }^{2}$}

Para ajudar a alcançar os objetivos desse estudo, solicitamos aos professores licenciados em História - e que atuam há anos na educação básica no município de Cáceres - para que respondessem a um pequeno questionário. Esta foi a forma escolhida para valorizar e dar visibilidade às práticas dos professores. Acreditamos que, investigações que se dediquem a compreender os fazeres dos docentes podem encorajar a uma contínua formação.

Para Miguel Zabalza (2004, p. 21), o professor é um sujeito racional porque ele entende o ensino em seu contexto prático e precisa buscar e encontrar soluções para dilemas práticos, sendo uns mais imediatos e outros, não. Esta flexibilidade constitui-se em uma condição profissional necessária. ${ }^{3}$ Os professores que atuam na educação básica estão em oposição aos professores universitários que, segundo Bourdieu, citado por Faria (2016, p. 320), pertencem mais ao polo denominado de campo do poder. ${ }^{4} \mathrm{E}$, assim, opõem-se francamente aos padrões da indústria e do comércio, ainda que intelectuais do campo da educação, engajados nas políticas em curso, apontem para o crescimento de uma educação mercadológica em vigor dentro e fora das universidades.

Inicialmente a Professora Ana, natural de São Paulo, graduada e doutora em História, cuja tese defendida em 2014 tem por finalidade apresentar os planos urbanos das reduções Guarani, Chiquitos, Mojos, e que tem como ponto de partida as experiências indígenas antes do contato com não indígenas e seu posterior estabelecimento em um novo espaço dado pelas chamadas reduções. Aos 35 anos de idade, a referida profissional afirma não estar de acordo com a frequência com que a História de Mato Grosso, bem como a História Local de Cáceres, são abordadas na escola.

O espaço dedicado as questões do Mato Grosso e Cáceres são dentro de conteúdos nacionais. Já temos inúmeras pesquisas e até um livro didático da autora Elisabeth Madureira, capaz de orientar os alunos em todos os períodos históricos. Sendo necessária uma aula a mais para ensinar algo tão importante para todos nós, além de formação continuada para professores para atualizarem sobre novas pesquisas em 
mestrado e doutorado. Além de incentivar os docentes a pesquisarem junto de seus alunos, temas regionais. (Professora Ana).

A temática História Regional e Local faz parte das atividades desenvolvidas pela Professora Ana. Segundo ela, as referências utilizadas para se trabalhar com os estudantes são artigos acadêmicos, dissertações, teses e revistas especializadas. A metodologia aplicada consiste em leitura de jornais impressos, documentos históricos (diários, cartas, ofícios do século XVIII).

Conforme a colaboradora explica, os assuntos que ela aborda, dentro da temática de História de Mato Grosso, vão desde a pré-história até o período Imperial. É certo que sua experiência, enquanto especialista em Mato Grosso Colonial, lhe confere uma maior autonomia para a condução de práticas no que se refere à História Regional.

A denominada Professora Luiza, natural de Cuiabá, também licenciada em História pela Universidade do Estado de Mato Grosso e especialista em Distúrbio de Aprendizagem, afirmou que adquiriu conhecimento acerca da História de Mato Grosso e de História Local através de outros professores na graduação, via Internet e de atividades artísticas na escola. Também discorda com a frequência com que a História de Mato Grosso e a História de Cáceres são abordadas na escola. Para a docente,

Gostaria de incentivo no estudo da cultura e o turismo. Já que Cáceres foi eleita patrimônio cultural do Brasil. A importância de conhecer a nossa história em que a diversidade cultural é imensa e isso ajuda na preservação e resgate de tradições, podendo assim a compreender a nossa própria identidade. (Professora Luiza).

Na Escola B, nosso entrevistado, Professor Lucas, é graduado em História pela Universidade do Estado de Mato Grosso, cuja especialização tratava da redemocratização na fronteira Brasil-Bolívia. O Professor Lucas é natural de Cáceres e disse concordar com a frequência com que a História de Mato Grosso, bem como a história Local são abordadas em aula. Segundo ele,

Ainda na educação brasileira, predomina a história europeia e história geral, por essa razão e pela importância da população mato-grossense como sujeito histórico deve ser abordada não só no ensino médio, mas nas séries iniciais do ensino fundamental, o mesmo ocorrendo com a história de Cáceres, município riquíssimo em história. (Professor Lucas).

Apesar de nos planos de ensino das Ciências Humanas não constar conteúdos acerca da História Regional e/ou Local, o Professor Lucas disse trabalhar com a temática e que utiliza 
artigos acadêmicos, assim como as redes sociais como referências para ministrar suas aulas. Também busca ministrar aulas práticas e aulas de campo, como "visitas em sítios arqueológicos, museus, patrimônios tombados nos perímetros urbanos e rural (sic)". O conhecimento obtido sobre a História Regional e Local, segundo ele, foi através de jornais impressos, revistas, livros didáticos, professores, amigos, Internet, graduação e na pósgraduação.

O Professor Fernando, que também atua na Escola B, é licenciado em História pelo Centro de Estudos Superiores de Maceió, Alagoas e possui especialização em Educação Ambiental. Segundo o referido docente, raramente aborda o tema História Regional em suas aulas. O mesmo tomou conhecimento a respeito da temática através de jornais impressos, revistas e livros didáticos. Ato contínuo, afirmou não ter acesso a materiais que envolvessem o conteúdo. O Professor Fernando disse, ainda, não concordar com a frequência com que o tema é discutido na escola, mas o considera relevante: "É importante que os estudantes estudem a história de seu Estado e sua cidade em todas as fases pelo menos um bimestre."

Importante assinalar que a importância da docência em História, de acordo com Samara Mendes de Araújo Silva (2011), está vinculada "a construção cotidiana dos conhecimentos compreensíveis e compatíveis com o desenvolvimento intelectual e emocional dos sujeitos do processo de ensino-aprendizagem da ciência Histórica". Desta forma, para a autora:

\begin{abstract}
Então, o exercício do Ensino da História se faz e se constrói a partir da articulação entre: referencial teórico-metodológico da História, análise-interpretação das fontes (informações) sobre o fato histórico, competências e habilidades didáticopedagógicas, objetivando a recomposição de dados e informações históricas e metodologias de ensino para a elaboração de conhecimentos históricos destinados e compatíveis com a maturidade intelectual dos discentes a que estes são apresentados. $^{5}$
\end{abstract}

A despeito das respostas dos professores que atuam no cotidiano do chão da escola que, conforme seus próprios Projetos Pedagógicos, apontam para as dificuldades vivenciadas por ela - encontramos em suas respostas que, a dinâmica do ensino de História Regional e/ou História Local, acontece dentro dos planejamentos paralelos aos planos de ensino. Ou seja, não necessariamente estão organizados, sistematizados e documentados em textos. Entretanto, eles existem na medida em que o professor estabelece uma conexão entre o nacional, o regional e o local. Esta compreensão se evidencia muito mais durante as conversas informais com os professores, que aparentemente se sentiam mais à vontade para falar do que para descrever em poucas palavras suas experiências em um questionário. 
Esta conexão acontece da seguinte maneira: o tema de caráter nacional é debatido e, frequentemente, é abordado como reflexos ao contexto regional e/ou local em dado momento histórico. Uma estratégia que busca localizar o estudante e colocá-lo como sujeito ativo e que perceba o referencial dado, oportunizando, assim, o seu posicionamento crítico e reflexivo sobre o assunto.

Embora tenha sido possível visualizar nos planos impressos e entregues às secretarias das respectivas escolas uma concepção empirista acerca da disciplina História, supõe-se que esta concepção venha a reduzir o ensino/aprendizagem do ensino de História Regional e Local a um domínio de conceitos, fatos, feitos e datas.

Entendemos que o ato de planejar uma aula não seja uma tarefa fácil, ao passo que se levarmos em consideração as demandas existentes na escola - como, por exemplo, a quantidade e a diversidade de estudantes por turma, as necessidades específicas deles, a carga horária de trabalho semanal, além das demandas das orientações curriculares - os professores do Ensino Fundamental e Médio se deparam com o desafio de escolha de conteúdo, metodologia e atividades.

\section{Delineando a fala dos jovens do Ensino Médio de duas escolas estaduais de Cáceres ${ }^{6}$}

Numa sociedade do conhecimento com graus de complexidade crescente, a preparação de todos os cidadãos para a vida e para o mercado de trabalho requer o domínio de competências e habilidades de leitura, escrita, capacidade de resolver problemas e de entender o mundo que os cerca. Habilidades que, por certo, apenas uma minoria de jovens brasileiros obtém ao chegar à idade adulta. ${ }^{7}$

Destacamos, aqui, a importância que foi buscar nos jovens estudantes das escolas pesquisadas, a sua percepção quanto ao ensino de História Regional e Local na vida escolar e enquanto sujeitos do lugar onde vivem. Além disso, assinalamos que o conhecimento histórico pode ser provisório, incompleto e seletivo. Porém, não inverídico e simplesmente restrito às perguntas feitas à evidência. (Thompson, 1981). ${ }^{8}$

Desde a Antiguidade Clássica, a História, enquanto campo de conhecimento científico, vem ocupando um lugar definido na formação dos jovens. De acordo com Abud (2011, p. 163-171), quando as formas de educação existentes eram reservadas exclusivamente aos jovens pertencentes à elite, a História que lhes era ensinada tinha o compromisso com sua formação como "prováveis futuros líderes militares e chefes de governo". 9 Por isso, ao 
conhecimento histórico se atribuíam objetivos relacionados à oratória, à ordenação, à memória e à formação moral dos sujeitos.

Longe de nos aprofundarmos na categoria jovem e juventude - não sendo nosso propósito da pesquisa em curso - delineamos o perfil dos discentes que fazem parte das escolas públicas estaduais: jovens, filhos de pais trabalhadores que, na busca por um espaço privilegiado no mercado de trabalho, buscam na educação pública o seu acesso.

Dentro dos limites deste texto, categorias como gênero, aproveitamento escolar e renda familiar não foram considerados como objetos de investigação. Entretanto, entendemos como relevante para esta pesquisa, assinalar as origens destes jovens estudantes. Todavia, é importante registrar também que, ao sistematizar as informações, não fizemos qualquer hierarquização entre os estudantes das escolas.

Na Escola A, responderam ao roteiro/questionário 26 estudantes, a maioria tinha entre 15 a 18 anos de idade quando o questionário foi aplicado. Os estudantes estavam distribuídos entre os $1^{\circ}$ anos e os $3^{\circ}$ anos do Ensino Médio. A escolha por esta etapa da educação básica previa que o conhecimento acerca de temáticas que envolvessem o Ensino de História Regional e Local já fizesse parte da trajetória escolar destes estudantes.

Em relação ao conhecimento de História Regional e/ou Local na Escola A, metade dos estudantes responderam não saberem nada, pouco ou não se lembrarem de nada sobre o que estudaram na escola; 38\% dos estudantes disseram conhecer a História de Mato Grosso do período colonial; $8 \%$ dos estudantes fazem referência a lendas da cidade de Cáceres no que diz respeito aos seus conhecimentos acerca da História Local; e 4\% dos estudantes responderam conhecer um pouco sobre a cidade de Cáceres, por sua importância como cidade histórica.

Quanto à pergunta, os estudantes da Escola $A$ comentavam entre si e tentavam ajudar nas respostas dos colegas. Ali, já manifestavam certa reflexão sobre o que estudavam ou não; sobre o que sabiam ou não acerca das temáticas. Ainda que se posicionassem em suas falas, os estudantes foram breves em suas respostas. As respostas ao questionário sobre os conhecimentos acerca da História de Mato Grosso e História Local estão inseridas abaixo, respectivamente, com a interface pautada na historiografia mato-grossense.

Segundo a estudante Fernanda, "não me recordo, pois, sobre Mato Grosso a história é pouco trabalhada". Acerca da História Local ela pontuou que "Cáceres é uma cidade que cresceu após o período colonial, sem organização futura de adaptação". Em relação à frequência com que a História de Mato Grosso e a História Local são abordadas na escola, a 
estudante disse não concordar, porque "é raramente trabalhada a questão da história de Cáceres. Ou seja, não há um foco para isso".

Na fala de Fernanda, percebe-se que, no contexto após a colonização, a cidade não tinha um projeto definido de modernização. Contudo, no limiar do século XIX, a então província de Mato Grosso buscava alcançar acesso à Corte, na tentativa de acompanhar a "modernização" proveniente do Império brasileiro e, assim, romper com o isolamento em relação às demais regiões do país. Para Rachel Pinho (2011), Cáceres, no fimm do século XIX especialmente após o término da Guerra do Paraguai, em 1870 - teve, com a abertura da navegação pelo rio, a almejada transformação em seu cenário urbano. E, assim, a cidade não seria mais a mesma:

\begin{abstract}
$\mathrm{Na}$ barranca da baía, em frente à pequena Igrejinha, vapores, lanchas e paquetes de variados calados atracavam trazendo mercadorias vindas da Europa como tecidos, azeites, cristais, pianos, materiais de construção, novidades, quinquilharias que logo iam sendo incorporadas ao figurino local, sobretudo das pessoas mais abastadas, mas não apenas destas. Não eram apenas mercadorias que aportavam em Vila Maria do Paraguai, também desembarcavam ideias, ciência, modas e modismos transformando a paisagem e a economia local. ${ }^{10}$
\end{abstract}

Ainda sobre as transformações alavancadas pela abertura da navegação do rio Paraguai neste contexto após guerra, Cristiane Cerzósimo Gomes (2018, p. 218) assinala:

Para o Império brasileiro e especialmente para a província de Mato Grosso, o Tratado Especial de Navegação com o Paraguai não só estabeleceu uma importante hidrovia de comunicação com o exterior, como firmou relações comerciais com os países do Prata e os europeus. Abriu-se nova fase de prosperidade econômica, social e cultural em terras mato-grossenses e um movimento sem precedentes de importação de produtos nacionais e estrangeiros, viabilizando também a exportação de produtos nacionais e estrangeiros, viabilizando também a exportação da produção regional para diferentes províncias brasileiras e países. ${ }^{11}$

"Não lembro", afirmou Larissa. Mas depois reconsidera a afirmação: "eu sei sobre alguns contos que o povo conta sobre a cidade de Cáceres. A história de alguns casarões antigos". A estudante disse não concordar com a frequência com que a História Regional é abordada, pois "deveria falar mais um pouco sobre". ${ }^{12}$

Nota-se na resposta de Larissa e, mais adiante na de outros estudantes, as referências sobre o patrimônio material da cidade de Cáceres. São mencionados: a catedral São Luís de Cáceres e os casarões, que se misturam numa paisagem do encontro entre o passado e o presente e que são elementos materiais e simbólicos. Tanto a catedral quanto os casarões são celebrados pelos estudantes - ainda que sua existência não seja questionada - o que, sem as 
orientações de um historiador, pode-se levar a interpretações das mais diversas. Se cabe ao historiador fazê-lo, então:

[...] a crítica do documento - qualquer que ele seja - enquanto monumento. $\mathrm{O}$ documento não é qualquer coisa que fica por conta do passado, é um produto da sociedade que o fabricou segundo as relações de força que aí detinham o poder. Só a análise do documento enquanto monumento permite à memória coletiva recuperá-lo e ao historiador usá-lo cientificamente, isto é, com pleno conhecimento de causa. (Le Goff, 1994, p. 594). ${ }^{13}$

Assim, o que os estudantes conseguem enxergar como patrimônio, pode ser contextualizado historicamente na tentativa de inserir sentido ao seu próprio tempo. Para Rubens Lacerda (2011, p. 200):

[...] percebermos como todo um arcabouço de memória foi construído/inventado, dentro de uma relação de poder/saber, acabamos por (des)sacralizar esta memória que visa construir uma identidade cacerense a partir de apenas alguns exemplos da História vivida. ${ }^{14}$

Neste sentido, Le Goff (1994) define memória como “essencialmente mítica, deformada, anacrônica, mas constitui o vivido desta relação nunca acabada entre o presente e o passado". É, portanto, para o historiador francês, desejável que a informação histórica, fornecida pelos próprios historiadores - e que é vulgarizada pela escola (ou pelo menos deveria sê-lo) e os mass media - corrija esta história tradicional falseada. A história, então, deve esclarecer a memória e ajudá-la a retificar os seus erros. ${ }^{15}$

As estudantes Luiza e Isabela destacaram os temas da cultura e tradições da cidade de Cáceres e do estado de Mato Grosso:

Que fala sobre os indígenas que mora (sic) na fronteira, sobra as culturas, que em cada lugar do estado de Mato Grosso" e "é sobre a cultura, coisa antiga que está até hoje em pé, como era Cáceres antes até hoje. ${ }^{16}$

"As tradições e culturas do Mato Grosso, danças, cantos, comidas típicas" e "sei que Cáceres nem sempre foi Cáceres, já foi adotada por outros nomes, como São Luiz de Cáceres". Cáceres foi ocupada por colonizadores e as ruas pequenas e casas antigas são características desse período. ${ }^{17}$

De acordo com a estudante Camila, "Sei que os indígenas ajudaram na colonização do estado; a nossa produção de algodão e soja, que são muito importes para a economia” e; "aprendi sobre as obras da cidade, objetos e culturas dos nossos antepassados; o nome da cidade, que várias vezes foi trocado. Já conheci lugares históricos que hoje em dia são preservados". Além de não concordar com a frequência com que a História Regional e Local 
é trabalhada, a estudante disse que "devíamos aprender mais sobre a nossa região, cultura e tudo que se envolva, não apenas em uma disciplina". ${ }^{18}$

É no espaço de fronteira que a então Vila Maria, hoje Cáceres, foi construída e povoada. Desde sua fundação, no ano de 1778, como no decorrer do século XVIII, a presença de indígenas em Vila Maria foi uma constante. Nota-se, agora, que os "indígenas" citados aparecem enquanto sujeitos que ocupavam espaço antes da chegada dos portugueses. Nota-se, também, que os aspectos culturais são revelados sobre a ocupação portuguesa da área pertencente aos espanhóis, pelo Tratado de Tordesilhas (1494). Segundo Marli Auxiliadora de Almeida (2011, p. 35-49):

O domínio português nas imediações de Vila Maria, iniciado pela opção de povoamento de indígenas provenientes da República boliviana, representava um aval à expansão territorial portuguesa ao território espanhol, contrariando as determinações do Tratado de Tordesilhas, assinado em 1494 pelas duas Coroas ibéricas. Conforme o tratado, a parte interiorana da América pertenceria à Espanha, mas Portugal aos poucos desrespeitava a linha imaginária de Tordesilhas sob o pretexto de fortificar a fronteira a oeste de seus domínios. ${ }^{19}$

Em relação à frequência com que a História Regional e Local aparece nas aulas de História, Isabela disse não concordar "porque é importante sabermos mais sobre nosso estado, para entendermos como chegamos aqui." ${ }^{20} \mathrm{O}$ "entendermos como chegamos aqui" perpassa pela discussão sobre Educação Patrimonial e o Ensino de História, devido às possibilidades de utilização do universo cultural, das possibilidades de leitura que se multiplicam e pela interpretação de mundo.

De acordo com Jaqueline Zarbato (2018, p. 34) "pode-se dizer que a Educação Patrimonial é um instrumento de alfabetização cultural que possibilita ao indivíduo fazer a leitura do mundo que o rodeia, levando-o à compreensão do universo sociocultural e da trajetória histórico-temporal". Nesse processo, continua a autora,

[...] a Educação Patrimonial favorece um diálogo permanente entre os agentes que são responsáveis pela preservação dos bens culturais e a fundamentação educacional como uma troca de conhecimento, visando, sobretudo o entendimento de que as formas de proteção e preservação de bens culturais. ${ }^{21}$

Para Zarbato (2018, p. 36), o conceito de educação patrimonial apresenta seus desafios para execução de sua metodologia, mas ele pode incentivar a leitura do mundo que nos cerca, bem como as relações com nosso ambiente. A autora cita a publicação do Instituto do Patrimônio Histórico e Artístico Nacional, (IPHAN): 
[...] a Educação Patrimonial constitui-se de todos os processos educativos formais e não formais que têm como foco o Patrimônio Cultural, apropriado socialmente como recurso para a compreensão sócio-histórica das referências culturais em todas as suas manifestações, a fim de colaborar para seu reconhecimento, sua valorização e preservação. Considera ainda que os processos educativos devem primar pela construção coletiva e democrática do conhecimento, por meio do diálogo permanente entre os agentes culturais e sociais e pela participação efetiva das comunidades detentoras e produtoras das referências culturais, onde convivem diversas noções de Patrimônio Cultural. ${ }^{22}$

Nesta perspectiva, a escola é um dos espaços privilegiados enquanto produtora de conhecimento no que tange às referências culturais, considerando-se que as escolas públicas brasileiras são um espaço heterogêneo e de encontro da diversidade étnica e cultural. Neste aspecto, o desenvolvimento de ações de socialização e de difusão do patrimônio cultural possibilita que diferentes atores sociais, como estudantes da educação básica, participem das ações e, portanto, possam contribuir com suas "múltiplas memórias" no que diz respeito à compreensão de uma cidade, de uma comunidade, de um grupo social, seus significados, seus atores etc. $^{23}$

Desde a década de 1960 ocorre um retorno no sentido da conservação do patrimônio arquitetônico, e este fenômeno amplia-se com a instituição de uma verdadeira política do patrimônio. Em relação a essa socialização e à difusão dos espaços de memória, foi elaborado um mapa com o percurso interpretativo para o conjunto arquitetônico tombado nos bairros e no centro de Cáceres.

Nathaly relata que "o estado do Mato Grosso [...] já foi um estado de grande área, mas foi dividido em duas partes, tornando Mato Grosso e Mato Grosso do Sul. E hoje é um dos maiores estados do país" e que "a Cidade de Cáceres foi uma cidade militar". A estudante disse concordar com a frequência com que a História Regional e Local é trabalhada na escola: "porque é importante saber a origem do estado e da cidade onde moramos". ${ }^{24}$

Acerca da divisão do estado de Mato Grosso, em 1977, Luiza Volpato (2011, p. 205) tece as seguintes afirmações:

[...] a divisão do Estado de Mato Grosso, prevista no PND, fez com que Cáceres se tornasse uma das principais cidades do novo Estado. Este será o alvo de grandes atenções do Governo Federal, o qual tem por objetivo injetar recursos financeiros prevendo o desenvolvimento da região. Vários planos desenvolvimentistas irão surgir objetivando trazer progresso para a área. De grande importância será todo esse desenvolvimento, mas antes que ele chegue é necessário salvaguardar a memória regional. Em nosso país, o desenvolvimento sempre vem acompanhado da destruição do velho e do antigo para a identificação do novo. No entanto, o passado faz parte da vida. É através da formação socioeconômica da região que se poderá elaborar planos de desenvolvimento adequados à área e que poderão trazer realmente um progresso. Ciente disto, a Prefeitura Municipal de Cáceres e a 
TURIMAT (Companhia de Turismo de Mato Grosso) decidiram organizar o Museu de Cáceres. ${ }^{25}$

"O passado faz parte da vida", de Luiza Volpato, vem somar à fala da estudante Nathaly sobre ser "importante saber a origem do estado e da cidade onde moramos", fortalecendo a narrativa a respeito da importância da produção de sentido histórico. Os estudos dessas narrativas contribuem para que se compreenda a interpretação dos estudantes, para que eles percebam a História enquanto campo de conhecimento científico e que ela está presente no cotidiano em que os sujeitos se relacionam.

"Mato Grosso era uma cidade muito pequena e com poucos habitantes. E também uma cidade com poucos recursos financeiros", destaca Kelly. Ela reconhece: "o que sei, é que Cáceres era uma cidade muito pequena, e que não tinha quase nada de recursos. Os casarões são muito antigos. E Cáceres ainda conserva esses casarões antigos". Ela também disse concordar com a frequência com que é ensinada a História Regional e Local: "Sim! Porque o que nós falamos é sobre a melhoria de Mato Grosso e de Cáceres, que precisa melhorar muito". ${ }^{26}$

Destacamos o "melhorar" e evidenciamos o discurso de que Mato Grosso está em constante transformação na percepção dos estudantes. E o estado, para ser inserido no cenário mais global, cujos discursos inflamados exigem que ele seja colocado nos "trilhos do progresso". O estudante Richard afirmou que "Mato Grosso foi um Estado pouco valorizado pelos fazendeiros do café. Assim, escolheriam Mato Grosso do Sul, por ser vizinho de São Paulo, achando que eram ricos como eles. Assim, teve a divisão de Estado". Quanto ao que sabe sobre história de Cáceres, fez o seguinte registro: "Cáceres era uma Província do Estado de Mato Grosso. Assim, com sua fundação, virou uma vila chamada Vila Maria do Paraguai e, depois, chamada São Luiz de Cáceres. Foi dado o nome do colonizador de Cáceres.”27

Para Marcos, "a história de Mato Grosso se inicia quando os bandeirantes vêm até aqui para explorar as riquezas naturais. Mediante isso, constantes transformações se deram no território mato-grossense; sendo, uma delas, a elevação de Vila Bela da Santíssima Trindade à capital". Ao comentar sobre a História Local relatou ter "visto que a cidade de Cáceres serviu como ponto estratégico para o reabastecimento de pessoas que viajavam de Cuiabá a Vila Bela. Essa passou por inúmeras mudanças, desde sua fundação em 1778. Sendo, uma delas, a construção de uma importante Igreja, a catedral”. No que se refere à frequência da disciplina, o estudante disse não concordar, "pois é muito pouco retratada no âmbito escolar, 
exclusivamente no Ensino Médio, o que prejudica o saber do cidadão cacerense sobre a história de sua cidade." 28

Existem histórias de um passado bandeirante e de uma História monumental, caracterizadas nas descrições e interpretações sobre o passado, o que influencia e constitui a realidade mais concreta e simbólica dos estudantes. O "passado" e a "exploração das riquezas naturais", atrelada ao papel do bandeirante vindo de São Paulo merecem ser destacados. Salgueiro (p. 269-300, 2017), analisa que estes elementos foram propulsores da idealização de uma identidade regional que se pretendia consolidar a partir da leitura dos editoriais das revistas de circulação no Estado nas décadas de 1960 , por exemplo. ${ }^{29}$ De acordo com o autor,

\begin{abstract}
É importante reiterar que desde o início do século XX houve uma busca por uma construção identitária para o Brasil e a figura do bandeirante esteve presente, extrapolando o discurso regionalista de São Paulo e de sua historiografia, exercendo - inclusive - forte influência na concepção de "civilização" e "progresso" em um estado como Mato Grosso, por exemplo. Conforme informa Silvia Raimundo, naquele momento, "o estudo do movimento das bandeiras também foi utilizado para destacar a singularidade do habitante de São Paulo e seu papel na conquista e, posteriormente, na ocupação do território". Por consequência, diz a autora que o "ideário proposto nas primeiras décadas do século XX foi decisivo, pois à medida que criou uma série de marcos simbólicos, produziu 'sentimentos', que, acolhidos pela população, se incorporaram à consciência regional/nacional" e o "espírito bandeirante se espalharia por todo o país cumprindo o papel de guardião do território e das tradições nacionais".
\end{abstract}

A estudante Maria, por exemplo, afirmou que: "Não lembro. Mas eu vi que Cáceres foi fundada 6 de outubro de 1778, pelo tenente de Dragões Antônio Pinto Rego e Carvalho". Ela concorda com a frequência das aulas e que "é importante aprender sobre a história do seu estado e da sua cidade." ${ }^{30}$

Em relação à história do estado, Lucas considerou: "Sobre Mato Grosso, é um dos estados mais ricos em cidades, território. Sabemos que Mato Grosso foi importante na descoberta do Brasil nos tempos antigos". No que concerne à História Local, destacou que "sabemos que aqui já foi um vilarejo, com um povo muito acolhedor, gentil com lendas e contos historicamente conhecidos no mundo no Brasil inteiro", e disse não concordar com a frequência das aulas: "podemos dizer que a história desta (sic), poderiam ser falados em todos os livros pois é um Estado e cidade historicamente famoso." 31

Era território espanhol, a cidade de Cáceres possuía ouro além de não ter sido fundada intencionalmente já que era apenas uma ponta para a defesa do território" sobre a frequência das temáticas, disse não concordar e que "é obrigação saber sobre onde mora. $^{32}$ 
Para Samuel, o que se sabe sobre Mato Grosso "é que antigamente era habitado apenas por indígenas e, com o passar do tempo, pessoas de outras regiões vieram para cá povoar e buscar uma nova vida." Em relação à História Local, o estudante afirmou que "Cáceres era habitada por índios chiquitanos ${ }^{33}$ e guatós, e, com o tempo, vários colonizadores vieram para Cáceres aplicar o modo de vida europeu aqui”. No caso da frequência das temáticas em sala de aula, disse concordar "porque é sempre bom estudar a história do lugar onde você vive, para não esquecer sua origem." $" 34$

De acordo com Samuel, "vários colonizadores vieram aplicar o modo de vida europeu aqui”. Podemos interpretar tal afirmação a partir de dois vieses: o primeiro seria por intermédio de uma leitura a partir do modo de produção empregado na colônia e, o segundo seria, tomando como exemplo, uma leitura historiográfica notável feita pelo historiador Ronald Rominelli, atento ao aspecto cultural e aos costumes. O "modo de vida", de que falou o estudante Samuel, se aproxima da última leitura, pois, remete à ideia de que os colonizadores viam nos colonizados os "necessitados" de uma intervenção europeia. Desta forma, estes rumariam a uma vida melhor; "uma vida pautada nos mesmos princípios e valores da cultura ocidental". No aspecto religioso, por exemplo, de acordo com Raminelli (1996) em Imagens da colonização: a representação do índio de Caminha a Vieira:

[...] os religiosos desejavam conduzir o índio para a última etapa da evolução. Para tanto, os ameríndios teriam de abandonar os vis costumes, converter-se e morrer como cristãos. Deste modo, a vida dos selvagens americanos seria absorvida pela temporalidade cristã, dividida entre o passado, o presente e o futuro. ${ }^{35}$

Destacamos também, na fala de Samuel, as "pessoas de outras regiões que vieram para cá povoar e buscar nova vida". A Revolução de 1930, de fato, marcou "a passagem de uma sociedade agrária para uma sociedade urbano-industrial", e o Estado substituiu a imigração estrangeira por uma "política de colonização em proveito das populações nacionais". Como consequência da institucionalização do processo de colonização, por parte do governo de Getúlio Vargas, a expansão da fronteira agrícola chegou a alguns estados como o de Mato Grosso. (Galvão, 2013). ${ }^{36}$

Criada em 1943, a Fundação Brasil Central, instituição incorporada à Expedição Roncador-Xingu, tinha por objetivo empreender a Marcha para o Oeste, iniciando um processo de reconhecimento - bem como o de povoamento da região - ao criar condições e infraestruturas a fim de que os migrantes adentrassem e se fixassem nesse território.

$\mathrm{Na}$ Escola B, também 26 estudantes, entre 15 e 18 anos, responderam ao roteiro/questionário. Todos cursavam entre os $1^{\circ}$ e $3^{\circ}$ anos do Ensino Médio regular. Ao 
contrário da Escola A, a Escola $B$ não oferta Ensino Médio integrado a cursos técnicos profissionalizantes.

Comparada à Escola A, esta tem um menor número de estudantes distribuídos, ainda que seja uma das que mais possuem estudantes matriculados nessa fase da educação básica. Assim, 62\% dos estudantes da Escola B responderam não se lembrar, saber pouco ou, não saber de nada sobre a História de Mato Grosso; 15\% dos estudantes responderam saber sobre história de Mato Grosso do período colonial; outros 15\% dos estudantes responderam que conhecem a História de Cáceres através de lendas e mitos; e 8\% dos estudantes conhecem a história local a partir do que conhecem como "casarões da cidade".

Segundo a estudante Bruna, "Eu sei sobre a origem de Cáceres, seu primeiro nome, porque ela virou uma cidade, o feito (sic) histórico que aconteceram (sic) aqui, os monumentos históricos, cultura etc. O que eu sei é sobre a colonização, sobre a cana-deaçúcar, milharal e sobre as lendas de Mato Grosso". Quanto à História Local, a estudante pontuou os seguintes temas: "Sobre a Catedral, sobre lendas da cátedra (do minhocão), e sobre Marechal Rondon". ${ }^{37}$

Negritamos a fala de Bruna, ao apontar a "colonização, cana-de-açúcar, milharal”. Estas referências fazem parte da resposta dos estudantes porque, de certa forma, há um discurso de modernização, que chegou ao estado de Mato Grosso desde os primeiros projetos de colonização do século XVIII; passando pela década de 1930 e, alcançando um fortalecimento entre as décadas de 1970 e 1990. A Superintendência do Plano de Valorização Econômica da Amazônia (SPVEA), criada em 1953, apontava áreas das regiões Norte e Centro-Oeste como fronteiras a serem incorporadas ao processo produtivo nacional. O que, mais tarde, de fato aconteceria, com a vigência da política federal de colonização, a partir de 1964.

A política de colonização fora retomada no contexto do regime militar, cuja estratégia visava à integração da Amazônia e do Centro-Oeste a outras regiões do Brasil, sob a égide ideológica de segurança e desenvolvimento nacional, com objetivos, também, de se abrir espaço para o capital estrangeiro e nacional e, desta feita, garantir espaço no mundo capitalista. Neste sentido, Moreno e Higa (2017) consideram que:

Politicamente, essas ações foram definidas e apresentadas como programas viabilizadores da "reforma agrária" e de promoção da política agrícola, embora estivessem associadas à expansão da fronteira econômica baseada na concessão de incentivos fiscais e financeiros a grandes empreendimentos capitalistas estabelecidos na região. Mas, nesse momento, essa política de colonização também tinha como objetivo desmobilizar os movimentos e organizações sociais de luta pela reforma agrária e pôr fim aos conflitos que vinham se acirrando no campo, em fins da década 
de 1960 e início da década de 1970, com a transferência dos trabalhadores rurais para áreas da Amazônia Legal. ${ }^{38}$

A presença desses projetos no Estado, segundo as autoras, pode ser explicada, em parte, pela sua transformação em área de fronteira agrícola, dentro do processo de desenvolvimento do capitalismo no país. No campo, esse processo provoca a concentração da terra, que se caracteriza pela monocultura, principalmente, de "cana-de-açúcar e milho". Esta prática se caracteriza, também, pela expulsão de pequenos produtores e trabalhadores rurais que, por sua vez, vão migrar para a periferia das cidades ou para as áreas de fronteira.

Além disso, de acordo com as autoras,

Grande parte dos projetos foi implantada em territórios de diversos povos indígenas, quase sempre com o conhecimento dos governos estadual e federal, que não só aprovaram os projetos particulares de colonização como também implantaram projetos oficiais nessas áreas. Populações indígenas foram extintas no contato com as frentes de expansão e frentes pioneiras, por confrontos e por doenças contraídas dos colonizadores. Os que sobreviveram foram transferidos para os "parques" ou "reservas" indígenas, migraram ou permaneceram em frações do seu antigo território, reconhecidas como áreas indígenas pelo governo federal. ${ }^{39}$

No que tange a menção ao Marechal Rondon, remete-se ao processo de integração nacional no início do século XX, a partir da rede de telegrafia, que passaria por Cuiabá e por algumas cidades no interior, cujos trabalhos foram coordenados pelo supracitado militar na década de 1910. Neste contexto, de acordo com Siqueira (2017):

Essas obras, projetadas durante o Império, tiveram sua realização na Primeira República. Os responsáveis foram o Coronel Ewerton Quadros e o Major Gomes Carneiro que, em 1890, foram nomeados para coordenar os trabalhos. Para estabelecer as ligações telegráficas no interior do extenso território mato-grossense, foi designado o mimoseano Cândido Mariano da Silva Rondon que, entre os anos 1900 e 1906, ergue 17 estações telegráficas. ${ }^{40}$

Após o sucesso, continua a autora:

Rondon, após o sucesso desse trabalho, foi nomeado para prosseguir a implantação da rede telegráfica, de Mato Grosso ao Amazonas. O sistema utilizado era do telégrafo a fio, transmitido através do código Morse [...] Para realizar os trabalhos de abertura das estradas, instalação dos postes e dos fios e até mesmo para o serviço de telegrafistas, Rondon utilizou como mão de obra os índios que, nesses serviços, eram considerados, depois de "pacificados", trabalhadores da nação. ${ }^{41}$

As "lendas" e "mitos" compõem a fala dos estudantes, e isso identifica nuances da História do cotidiano. André Victor Cavalcanti Cunha (2005), ao investigar “as apropriações das matrizes historiográficas presentes nas narrativas históricas escolares reinventadas em sala 
de aula" observou a ausência de narrativas históricas escolares baseadas na matriz teórica conhecida como Nova História, porque os professores estabeleciam uma posição secundária para os saberes oriundos desta. O autor afirma que, em nenhum momento da pesquisa encontrou docentes que trabalhassem seus conteúdos a partir da História do Cotidiano ou da História das Mentalidades. ${ }^{42}$

Diante desta realidade, em que parte da história local é transmitida por meio de narrativas de mitos e de lendas que, por sua vez, atribuem veracidade aos fatos de determinada época e lugar, assinalamos que estas formas de narrativas explicativas, através da oralidade, se transformaram em um importante condutor de informações e o ato de contar histórias resiste ao tempo. Segundo Everaldo Rocha (1999), podemos conceituar o mito como uma narrativa, e como:

[...] um discurso, uma fala. É uma forma de as sociedades espelharem suas contradições, exprimirem seus paradoxos, dúvidas e inquietações. Pode ser visto como uma possibilidade de se refletir sobre a existência, o cosmos, as situações de "estar no mundo" ou as relações sociais. ${ }^{43}$

Em relação ao episódio do "minhocão", diz a lenda que:

[...] o minhocão vivia no rio Paraguai. Os pescadores assustados, pediram a proteção para a Santa que os ajudassem nas pescarias. A Santa Nossa Senhora atendeu a oração e veio prender com seus fios de cabelos o temoroso minhocão. Após grande luta com ele ela retirou três fios, apenas três fios de seus cabelos, para prendê-lo. Sua cabeça ficou presa embaixo da igreja sobre sua vigilância, porém, seu corpo passa pela cidade e só sua calda ainda está sobre o rio, mas o minhocão não se contenta, esbraveja, reluta para se soltar. Segundo os mais antigos, a cada movimento dele acontece algo na cidade: a terra treme, abrem buracos no chão, o chão racha, e dizem mais, que ele está conseguindo se libertar, 2 fios já foram quebrados agora resta apenas um que ainda o segura. Portanto, cuidado os cacerenses, o minhocão pode se libertar a qualquer momento. ${ }^{44}$

A catedral São Luiz de Cáceres começou a ser construída no ano de 1919, sendo finalmente inaugurada apenas em 1965. Em 1949 sua estrutura interna fora comprometida e ruiu, fortalecendo, assim, o imaginário popular acerca da lenda do "minhocão", criatura mítica também chamada de "serpente". Sua construção compreende o seguinte contexto histórico: a colocação da pedra fundamental em 1919, em virtude das comemorações do bicentenário da capital de Mato Grosso, Cuiabá. Com a proposta de se construir réplicas da Catedral Notre Dame de Paris, tanto em Cuiabá quanto em Cáceres, indica-se, neste momento, um certo prestígio econômico e político da cidade. 
Cabe aqui apresentar outro item também pertencente ao imaginário popular, a lenda, que por sua vez também envolve o imaginário dos indivíduos. Sendo assim podemos definila, segundo Bayard ${ }^{45}$, enquanto uma tradição, um produto inconsciente da imaginação popular que reflete os anseios de um grupo ou de um povo; sua conduta depõe a favor de uma ação ou de uma ideia cujo objetivo é arrastar outros indivíduos para o mesmo caminho.

As narrativas dos estudantes apresentaram uma lógica sobre acontecimentos históricos específicos do passado e do presente, tais como: colonização, crescimento econômico, patrimônio material, diversidade étnica, no que diz respeito às contribuições dos indígenas na formação da cultura mato-grossense - embora os negros não tenham sido mencionados. Suas narrativas demarcam períodos particulares com vistas a apresentar considerações sobre o presente, o que Isabel Barca categorizou como "narrativas emergentes". É possível perceber que há também nestas narrativas certas sínteses sobre o avanço da modernização no Estado e como, através delas, os estudantes se percebem enquanto sujeitos, como se as ações dos colonizadores guiados pelos discursos do progresso fossem responsáveis pela construção da identidade mato-grossense.

Os planos de ensino dos professores de História que atuam nas escolas públicas nos mostram um pouco da relação que o ensino de História Regional e Local, formatado nos formulários que cumprem, tem com a obrigatoriedade junto às coordenações pedagógicas. Porém, os planos são documentos que, sozinhos, não dialogaram com a proposta inicial da pesquisa, que era a de saber como os professores trabalham, e se trabalham com História Regional e Local em sala de aula.

Conforme Renilson Ribeiro (2016),

A educação necessita com urgência de professores de História formados com conhecimento científico e cultural, autonomia intelectual e pensamento crítico. Afinal, ninguém ensina o que não aprendeu ou não teve a oportunidade de compartilhar. ${ }^{46}$

Portanto, foi através das suas vozes que se possibilitou a percepção de que existe sim, a tentativa da valorização das temáticas, pelo fato de elas "serem importantes". Não obstante, as práticas dependem muito de uma formação onde haja instituições superiores: menos precárias em seus currículos; corpo docente qualificado; bibliotecas e laboratórios de práticas bem equipados etc. Ainda que isto signifique ficar às margens do problema. 


\section{Considerações finais}

Ao longo do processo de leitura e de sistematização das respostas dadas pelos estudantes, acerca dos conhecimentos adquiridos na trajetória escolar sobre História Regional e Local, observamos que eles realizavam uma leitura sobre as temáticas sempre remetendo ao passado - quando utilizam termos como "antigamente" e/ou "naquela época". Nesse sentido, os estudantes têm, por costume, associar a História de Mato Grosso com as ocupações indígenas e dos não indígenas. Esta interpretação nos remete à estrutura pensada e executada pelas leis, instituições e livros que organizaram os primórdios da disciplina História no Brasil, embora sempre que o processo de ocupação e povoamento seja mencionado nas narrativas destes estudantes, a figura do negro não aparece em nenhum momento. Percebe-se que a figura do indígena segue a ideia do Brasil Monárquico e, mais tarde, do Brasil Império. Nos cenários citados, o índio é retratado como herói - por meio de um ideário romântico enquanto o negro simplesmente é eclipsado da história. (Mattos, 2000). ${ }^{47}$

De acordo com Osvaldo Cerezer (2015), existe um problema em se abordar sujeitos como o indígena e o negro em sala de aula. Isto porque,

\footnotetext{
Parte do problema relacionado às dificuldades de se trabalhar a questão da diversidade racial e cultural em sala de aula decorre das deficiências de muitos professores em sua formação inicial e continuada, o que merece uma análise mais aprofundada e uma discussão constante por parte dos cursos de formação de professores e instituições de ensino, do papel das políticas públicas voltadas ao atendimento da formação inicial e continuada e de melhores condições de trabalho. No entanto, essa situação, embora de difícil manejo, precisa ser compreendida e encarada como um desafio a mais na vida. ${ }^{48}$
}

Cerezer se aprofunda, posteriormente, na análise acerca das dificuldades sobre a prática do ensino da diversidade étnica e racial - desde a formação dos professores da educação básica - em sua tese de doutorado. Assim, coloca em relevo a análise sobre a adoção do disposto na Lei n. 10.639/03 e na Lei n. 11.645/08 nos currículos dos cursos de Licenciatura em História de Mato Grosso. Não obstante, o autor também identifica permanências, rupturas e possíveis mudanças no trato das questões raciais pelos cursos de História de Mato Grosso, a partir da implementação das referidas leis.

A pesquisa também analisou, a partir das vozes docentes, como as ações desenvolvidas nas escolas pelos professores iniciantes impactam no processo de utilização dos estudos sobre história e cultura da África, afro-brasileira e indígena na Educação Básica. Nota-se, na narrativa dos estudantes, que a constituição do estado de Mato Grosso está intimamente ligada ao ideal da "nação civilizada", pois apresenta condições de natureza geográfica positiva. Foi 
possível localizar, também, certo valor atribuído ao passado; à formação do povo e à importância de se tomar conhecimento acerca da sua História, pensando-se em conhecer suas “origens" e, "o lugar onde se vive". Muito embora conceitos como identidade e representação não apareçam explicitamente.

Quanto aos resultados da análise das respostas às questões propostas na pesquisa, apresentamos algumas narrativas concretas de estudantes do Ensino Médio de escolas estaduais e percebemos as convergências quanto à estrutura narrativa. Das supracitadas informações, destacamos a noção de tempo: "passado", "antigamente", "naquela época". Não obstante, são levantados temas como, por exemplo, "colonização" (sendo destaque para estudantes de ambas as escolas), a "modernidade" e a "modernização". Estes fatores caracterizam a realidade social, cultural e econômica; o que Isabel Barca (2012) chamou de "estruturas binárias de um certo passado e presente". Esta última característica ficou evidente na narrativa do estudante Marcos - assim como na de outros estudantes. ${ }^{49}$

A narrativa construída pelo estudante Marcos, por exemplo, colabora para assinalarmos o que é História para ele: além de se referir ao passado, é a História que teve início com a chegada dos bandeirantes. Neste sentido, antes da chegada do "desbravador" paulista, Mato Grosso era um espaço vazio ou o "sertão”. E sertão, de acordo com Janaina Amado (1995), é

[...] uma categoria construída primeiramente pelos colonizadores portugueses, ao longo do processo de colonização. Uma categoria carregada de sentidos negativos, que absorveu o significado original, conhecido dos lusitanos desde antes de sua chegada ao Brasil - espaços vastos, desconhecidos, longínquos e pouco habitados -, acrescentando-lhe outros [...]. Para o colonizador, "sertão" constituiu o espaço do outro [...] Que outro, porém, senão o próprio eu invertido, deformado, estilhaçado ? $^{50}$

Sobre o que sabem e aprenderam fora das aulas de História - internet, pais, amigos, televisão - ou até mesmo em sala de aula, é notável a visão ainda estigmatizada, por parte dos estudantes, sobre do Estado de Mato Grosso. Segundo esta representação, antes da chegada dos bandeirantes, o estado seria um lugar tomado pela "barbárie". Estava, portanto, condenado a permanecer marcado pelo seu atraso frente a outros espaços da nação. É evidente, no trabalho de Salgueiro $(2017)^{51}$ que os "retratos" pincelados sobre Mato Grosso não ficam restritos apenas ao ambiente da escola. Muito do que os mato-grossenses aprendem sobre sua própria história foi construído através de discursos de mídia de circulação em massa, como, por exemplo, as revistas pesquisadas pelo autor sul-mato-grossense. Nas análises dos professores que responderam ao questionário, evidenciamos as dificuldades de se trabalhar a História Regional e Local em sala de aula. Porém, devido a sua importância, o 
tema deve ser contemplado na formação dos estudantes. Assim, assevera Circe Bittencourt (2015),

A dificuldade dos historiadores diante dos conceitos e categorias de análise a serem selecionados e explicitados é uma constante em seu trabalho. Também para o professor de História o problema se apresenta, mas de maneira diferente. Em situação de ensino, há a necessidade de domínio da natureza específica do conhecimento histórico, além do desafio de saber como introduzir e encaminhar as tarefas de aprendizagem para alunos de diferentes idades e condições culturais. ${ }^{52}$

E no exercício do ofício dos historiadores, continua a autora,

[...] empregam conceitos específicos especialmente produzidos para a compreensão de determinado período histórico. Segundo alguns historiadores, existem "as noções históricas singulares" tais como Renascimento, mercantilismo, descobrimento da América, feudos medievais, cruzadas, República Velha. Muitos dos conceitos criados pelos historiadores tornaram-se verdadeiras entidades a designar povos, grupos sociais, sociedades, nações: "povos bárbaros", bandeirantes, colonato, donatários das capitanias, patriciado romano, democracia ateniense, mercadores. ${ }^{53}$

Para Bittencourt, a História escolar utiliza essas noções e conceitos com muita regularidade, a ponto de os mesmos determinarem conteúdos programáticos e constituírem capítulos de livros didáticos. Claro que esses conceitos e noções são - evidentemente necessários, no entanto, pondera a autora, é necessário que "se forneça uma descrição mais precisa deles, exatamente porque são expressões conhecidas por todos, e seu uso torna-se arriscado, em razão do significado que assumem em cada época”.

No que se refere às noções sobre História de Mato Grosso e de Cáceres, os estudantes aprendem de acordo com uma categorização, que é organizada a partir do acontecimento mais próximo ou mais familiar, que estão descritas nos planos de ensino dos professores. Para Lantier, citado por Kátia Abud (2005), é “a partir de um protótipo, de uma espécie de nível básico para uma compreensão mais sólida, que ocorrem as noções capazes de enriquecer tal nível de conceptualização por processos figurativos e, sobretudo por analogias". A partir desse protótipo proposto pelo autor, podemos avaliar que, no que diz respeito ao processo de ocupação do território de Mato Grosso, os professores se empenham em "transportar" o estudante ao centro deste acontecimento através da leitura de cartas, diários e documentos históricos. ${ }^{54}$

A história do "lugar", como objeto de estudo, ganha contornos temporais e espaciais. Não se trata, portanto, de conteúdos escolares da história local, de entendê-los apenas na história do presente ou de determinado passado. Trata-se sim, de buscar identificar a dinâmica do lugar, as transformações do seu espaço, bem como articular esse processo às relações 
externas, a outros lugares diferentes do que ocupam. Acerca dessa questão, Sandra Pesavento (1990) destaca que, no espaço acadêmico, percebe-se a persistência, mesmo em estudos recentes, do que ela chama de "visão estreita e tradicional das histórias regionais". Esse fenômeno ocorre ainda que, muitas vezes, os trabalhos produzidos encontram-se revestidos de técnicas e de métodos sofisticados de análises científicas. ${ }^{55}$

O ensino do objeto desta pesquisa, organizado nos planos de ensino, constitui resposta à crítica ao "quadripartismo francês" e à visão eurocêntrica de História - pontuados por um dos professores que entrevistamos. Contudo, o eurocentrismo acaba sendo substituído pelo sudestecentrismo, isto é, por uma História do Brasil calcada nos mitos nacionais e em narrativas político-econômicas onde se toma o eixo Sul-Sudeste como modelo de referência hegemônico.

Neste contexto, Janaína Amado (1995) defende que

\begin{abstract}
A historiografia nacional ressalta as semelhanças, a regional, lida com as diferenças, com multiplicidade. [...] A historiografia regional tem ainda a capacidade de apresentar o concreto e o cotidiano. $\mathrm{O}$ ser humano historicamente determinado, ele fazer a ponte entre o individual e o social. [...] Apesar de toda essa riqueza de possibilidades, a historiografia regional conhece algumas dificuldades específicas. Em grande parte, decorrentes do tipo de relação mantida entre os centros hegemônicos do país, os polos socioeconômicos e culturais, e as regiões periféricas, mais pobres, e de como as pessoas vivenciam e introjetam essas relações. [...] $\mathrm{O}$ tema história e região é não só importante, como extremamente interessante, podendo ser abordado por diversos ângulos. ${ }^{56}$
\end{abstract}

Para Maria Lima (2017), as pesquisas que enfatizam a atividade docente têm apontado que, apesar de todo o desenvolvimento do conhecimento histórico que ocorreu ao longo do século XX, há ainda a permanência de práticas voltadas para uma concepção empirista do ensino e da aprendizagem. Segundo a autora, esta prática é "forjada no âmbito do projeto nacionalista do século XIX, a qual associa a uma concepção positivista da História." ${ }^{57}$

Kátia Abud (2001), em seu ensaio intitulado "Processos de construção do saber histórico escolar", corrobora com a análise de Lima no que tange os limites do ensino e aprendizagem e ainda considera ser notável que os processos analógicos aconteçam de tal modo, que os estudantes percebam a relação entre fatos do passado e do presente - e não somente em relação a dois fatos do passado, seja ele próximo ou distante. ${ }^{58}$ Para abordar os temas propostos, os estudantes utilizam-se de representações construídas dentro e fora da escola. Então, os conhecimentos adquiridos fora dos muros escolares podem trazer luz a experiências fora do ambiente escolar e, já revelam certo "esforço de compreensão histórica." 
Foi possível perceber nas narrativas históricas construídas, tanto pelos estudantes da Escola A quanto pelos estudantes da Escola B, bem como pelos professores, duas escolas historiográficas: a primeira, a escola a "rankeana", derivada do nome do historiador Leopold von Ranke (1795-1886). Este propunha apresentar os fatos tais como "foram na realidade". Neste quadro, conforme Bentivlogio (2014), os historiadores europeus propunham criar os grandes esquemas políticos e institucionais. ${ }^{59}$ Para Peter Burke (1992), este paradigma se refere à política. Assim, constitui-se, essencialmente, em uma narrativa de acontecimentos. Outros historiadores da sua mesma linha a denominaram de "visão de cima" no sentido de ela estar ancorada nos feitos e realizações dos grandes homens e de ser baseada em documentos. ${ }^{60}$

A outra escola historiográfica é a marxista, surgida no século XIX, que apresenta um contraponto ao paradigma anterior, de viés reducionista, em que situações históricas complexas são lidas como mero jogo de poder entre grandes homens ou países e se caracteriza, também, por uma espécie de "tirania" do fato ou do documento. Estes fatos e documentos são importantes, mas não devem levar à abdicação de outros tipos de evidências. No entanto, a interpretação econômica só viria a se concretizar com o aparecimento do Materialismo Histórico, de Karl Marx e Friedrich Engels. Estes dois pensadores do século XIX defendem que a História se constitui, essencialmente, em uma "descrição" da luta de classes - que coloca em lados opostos explorados e exploradores. A economia passa a constituir um aspecto de capital importância na evolução das sociedades, notadamente no tocante à posse dos meios de produção. ${ }^{61}$

Diante do exposto, não deixamos de observar que o trabalho seja voltado para a busca do conhecimento histórico. Com crítica, reflexão e debate, ele se constitui em um desafio para professores e estudantes que buscam se colocar como sujeitos do processo de ensino. Seguindo este raciocínio, defendemos que tal busca depende da dedicação e do compromisso frente a situações e ideias diversas, que dão sentido a diferentes experiências desses sujeitos em seu tempo e espaço. Nesta pesquisa foi possível compreender que há o desafio de se ensinar História, por razões que são constantemente temas de trabalhos e que atravessam décadas a fio neste país. Entretanto, ensinar História Regional e Local parece ser uma tarefa ainda mais desafiadora quando se observa e analisa qualitativamente narrativas de estudantes sobre essas temáticas. Podemos ler que, em meio aos debates sobre as visões de história que permeiam as propostas curriculares desde a década de 1980, configurou-se um campo profícuo a ser explorado, em que se encontram possibilidades de diálogo entre escolas e outras instituições que se disponham pela prática educativa, como as universidades. 
Ainda que as universidades estejam operando com públicos e níveis discursivos distintos, estas instituições podem potencializar os conteúdos gerados por suas pesquisas, cruzando-os com práticas pedagógicas que envolvam uma etapa mais básica do percurso formativo. Exemplo disso são as linhas de pesquisas dentro das universidades, com projetos voltados para "elaboração de material didático instrucional de História de Mato Grosso para o ensino de $2^{\circ}$ grau" ainda na década de 1980. (Canavarros et al., 2012). ${ }^{62}$

Em outra época, outro contexto, os acontecimentos históricos deveriam ser memorizados e as avaliações, repletas de feitos heroicos. Atualmente, com pesquisas dedicadas à elevação do conhecimento científico e mais prático, sabemos que a aprendizagem não acontece desta forma, e, uma das maiores dificuldades é de se romper com essa história datada, arraigada nas nossas escolas.

Promover um outro olhar para a disciplina sempre vem com um pouco de insegurança, pois, as datas e as informações factuais ainda estão muito presentes e, dado este cenário, o livro didático ainda é a única fonte de pesquisa, principalmente nos rincões mais afastados do país. Assim, o professor recorrerá a outras fontes e repensará sua prática, pois, a história baseada em grandes vultos e seus "notáveis" feitos não será capaz de responder, satisfatória e plenamente, às questões atuais.

Podemos destacar nas análises das narrativas discentes, que as formas institucionais e culturais da História de Mato Grosso e de Cáceres privilegiam acontecimentos históricos ancorados no discurso econômico tomando-se como referência a região Sudeste do Brasil. Esta visão fora denominada nesta pesquisa de sudestecentrista. Por esta razão, chamamos a explicação do tema proposto para um determinado viés, que é o da noção de que o sudeste brasileiro seria - de acordo com o senso comum - o centro político, econômico, cultural e social do país. Desta forma, esta região político-geográfica seria a que determina o desenvolvimento das demais regiões do Brasil, como sendo um exemplo de modernização e avanço tecnológico a ser seguido.

\section{Notas}

\footnotetext{
${ }^{1}$ Cf. SOUZA, S. C. S. O que vocês sabem sobre história de Mato Grosso?: Ensino de História Regional e Local nos planos de ensino das escolas estaduais de Cáceres/MT. Dissertação (Mestrado em História). Universidade Federal de Mato Grosso. Cuiabá, 2019.

${ }^{2}$ A identidade dos professores foi preservada por meio de uso de pseudônimos.

${ }^{3}$ ZABALZA, M. Diários de aula: um instrumento de pesquisa e desenvolvimento profissional. Porto Alegre: Artmed, 2004, p. 21.
} 
${ }^{4}$ Citado por FARIA, P. C. J. Do campus universitário ao campus socialis: Em busca da universidade pública. Mulemba. Luanda. v. 6, n. 11, p. 317-324, 2016, p. 320.

${ }^{5}$ Samara Mendes Araújo Silva busca em seu artigo apresentar um instrumental que possa servir aos professores de história a adotarem uma atitude reflexiva sobre sua prática docente e pela busca por novas estratégias de ensino viáveis para o ensino da História do Local. SILVA, S. M. A. Novas metodologias no ensino de História Local: a gincana cultural como estratégia didática para o Ensino de História no Piauí. Anais do XXVI Simpósio Nacional de História - ANPUH São Paulo, julho 2011. Disponível em: https://anpuh.org.br/index.php/documentos/anais/category-items/1-anais-simposios-anpuh/32-snh26 Acesso em: 28 mai. 2021

${ }^{6}$ Os nomes dos estudantes entrevistados na pesquisa são pseudônimos para preservar sua identidade.

${ }^{7}$ CASTRO, M. H. G.; TORRES, H. G.; FRANÇA, D. Os jovens e o gargalo do Ensino Médio brasileiro. São Paulo: Fundação Sistema Nacional de Análise de Dados, 2013. Disponível em: https://www.seade.gov.br/wpcontent/uploads/2014/06/Primeira_Analise_n5_agosto_2013.pdf. Acesso em: 20 jun. 2021.

${ }^{8}$ THOMPSON, E. P. A miséria da teoria: ou um planetário de erros - uma crítica ao pensamento de Althusser. Rio de Janeiro: Zahar Ed., 1981.

${ }^{9}$ ABUD, K. M. Conhecimento histórico e ensino de história: a produção de conhecimento histórico escolar. In: Encontros com a história, n. 2. Sujeito na história: práticas e representações. Bauru: Edusc, 2001. Cf. também: ABUD, K. M. A guardiã das tradições: A História e seu código curricular. Educar. Curitiba, n. 42, p. 163-171, out./dez. 2011.

${ }^{10}$ PINHO, R. T. Cáceres: Olhares sobre a tessitura urbana de São Luís de Cáceres. In: CHAVES, O. R.; ARRUDA, E. F. (Org.). História e Memória Cáceres. Ed. Unemat, 2011, p. 66-80.

${ }^{11}$ GOMES, C. T. A. C. Mato Grosso: imigração, comércio e navegação na Bacia do Prata. In: RODRIGUES, C. M.; NETO, V. J. (Org.). Nova História do Mato Grosso Contemporâneo. Cuiabá: EdUFMT, 2018, p. 28.

${ }^{12}$ Larissa, 16 anos, negra, natural de Cáceres, estudante da Escola A.

${ }^{13}$ LE GOFF, J. História e memória. Campinas: Ed. Unicamp, 1994, p. 594.

${ }^{14}$ LACERDA, R. G. Instantâneo histórico de Cáceres. In: CHAVES, O. R.; ARRUDA, E. F. (Org.). História e Memória Cáceres. Cáceres: Ed. Unemat, 2011, p. 200.

${ }^{15}$ LE GOFF, J. História e memória. Campinas: Ed. Unicamp, 1994, p. 22.

${ }^{16}$ Luiza, 16 anos, parda, natural de Cáceres, estudante da Escola A.

${ }^{17}$ Isabela, 16 anos, amarela, natural de Cáceres, estudante da Escola A.

${ }^{18}$ Camila, 16 anos, negra, natural de Cáceres, estudante da Escola $A$.

${ }^{19}$ Cf. ALMEIDA, M. A. A Presença indígena em Vila Maria do Paraguai: os Bororo Cabaçal. In: CHAVES, O. R.; ARRUDA, E. F. (Org.). História e Memória Cáceres. Cáceres: Ed. UNEMAT, 2011, p. 35-49.

${ }^{20}$ Isabela, 16 anos, amarela, natural de Cáceres, estudante da Escola A.

${ }^{21}$ ZARBATO, J. A. M. Patrimônio, cultura e processos educativos em história: percursos e reflexões. Campo Grande: Life Editora, 2018, p. 34.

${ }^{22}$ ZARBATO, J. A. M. Patrimônio, cultura e processos educativos em história: percursos e reflexões. Campo Grande: Life Editora, 2018, p. 36.

${ }^{23}$ ZARBATO, J. A. M. Patrimônio, cultura e processos educativos em história: percursos e reflexões. Campo Grande: Life Editora, 2018, p. 34.

${ }^{24}$ Nathaly, 15 anos, parda, natural de Cáceres, estudante da Escola A.

${ }^{25}$ Citado por LACERDA, R. G. Instantâneo histórico de Cáceres. In: CHAVES, O. R.; ARRUDA, E. F. (Org.). História e Memória Cáceres. Cáceres: Ed. Unemat, 2011, p. 205.

${ }^{26}$ Kelly, 18 anos, parda, natural de Cuiabá, estudante da Escola A. Na sua resposta, a estudante confunde Estado com cidade para abordar Mato Grosso.

${ }^{27}$ Richard, 17 anos, natural de Cáceres, pardo, estudante da Escola A.

${ }^{28}$ Marcos, 17 anos, negro, natural de Cáceres, estudante da Escola A. 
${ }^{29}$ SAlguEIRO, M. M. Fugindo do estigma: visões sobre Mato Grosso nas páginas da Série Realidade Brasileira e da Revista Brasil-Oeste. Anos 90. Porto Alegre, v. 24, n. 46, p. 269-300, dez. 2017.

${ }^{30}$ Maria, 16 anos, negra, natural de Cáceres, estudante da Escola A.

${ }^{31}$ Lucas, 17 anos, natural de Cáceres, estudante da Escola A.

${ }^{32}$ Ítalo, 17 anos, branco, natural de Cáceres, estudante da Escola $A$.

${ }^{33}$ O povo Chiquitano foi constituído a partir de um amálgama de grupos indígenas aldeados no século XVII pelas missões jesuíticas. Habitantes da região de fronteira entre Brasil e Bolívia, foram compulsoriamente envolvidos em conflitos políticos e diferenças culturais decorrentes de uma divisão territorial que não lhes dizia respeito. A grande maioria desse povo está na Bolívia. Os que moram no Brasil têm sido explorados como mão de obra barata por fazendeiros, os quais também representam uma ameaça constante de invasão aos poucos territórios que lhes restam. Mas os Chiquitano têm lutado pelo direito a uma Terra Indígena, que está em processo de identificação pela FUNAI e que poderá assegurar a continuidade de sua identidade cultural. Povos Indígenas no Brasil, Disponível em: https://pib.socioambiental.org/pt/Povo:Chiquitano. Acesso em: 15 abr. 2021.

${ }^{33}$ Os Guató, considerados o povo do Pantanal por excelência, ocupavam praticamente toda a região sudoeste do Mato Grosso, abarcando terras que hoje pertencem àquele estado, ao estado de Mato Grosso do Sul e à Bolívia. Podiam ser encontrados nas ilhas e ao longo das margens do rio Paraguai, desde as proximidades de Cáceres até a região do Caracará, passando pelas lagoas Gaíba e Uberaba e, na direção leste, às margens do rio São Lourenço. No interior deste vasto território sua presença foi registrada desde o século XVI por viajantes e cronistas.

${ }^{34}$ Samuel, 17 anos, branco, natural de Cuiabá, estudante da Escola A.

${ }^{35}$ Cf. ROMANELLI, R. Imagens da colonização: a representação do índio de Caminha a Vieira. Rio de Janeiro: Zahar Ed., 1996.

${ }^{36}$ GALVÃO, J. A. C. Notas sobre a colonização em Mato Grosso de 1940 a 1980. V Seminario Internacional de Investigación en Urbanismo, Barcelona-Buenos Aires, jun. 2013. Barcelona: DUOT, 2013, p. 58-64.

${ }^{37}$ Bruna, 17 anos, parda, natural de Vila Bela da Santíssima Trindade, estudante da Escola B.

${ }^{38}$ MORENO, G.; HIGA, T. C. S. Geografia de Mato Grosso: território, sociedade, ambiente. 2. ed. revisada e atual. Cuiabá: Entrelinhas, 2017.

${ }^{39}$ MORENO, G.; HIGA, T. C. S. Geografia de Mato Grosso: território, sociedade, ambiente. 2. ed. revisada e atual. Cuiabá: Entrelinhas, 2017.

${ }^{40}$ SIQUEIRA, E. M. História de Mato Grosso: da ancestralidade aos dias atuais. 2. ed. atual. e ampl. Cuiabá: Entrelinhas, 2017.

${ }^{41}$ SIQUEIRA, E. M. História de Mato Grosso: da ancestralidade aos dias atuais. 2. ed. atual. e ampl. Cuiabá: Entrelinhas, 2017.

${ }^{42}$ CUNHA, A. V. C. Invenção do saber histórico escolar: apropriações das narrativas históricas escolares pela prática pedagógica dos professores de história. Dissertação (Mestrado em Educação). Universidade Federal de Pernambuco. Recife, 2005.

${ }^{43}$ ROCHA, E. O que é mito? São Paulo: Brasiliense, 1999. (Coleção primeiros passos 151).

${ }^{44}$ A lenda do Minhocão de Cáceres. Disponível em https://maismirassol.wordpress.com/2012/10/10/a-lenda-dominhocao-de-caceres/. Acesso em: 8 jan. 2019.

${ }^{45}$ Citado por ROCHA, E. O que é mito? São Paulo: Brasiliense, 1999. (Coleção primeiros passos 151).

${ }^{46}$ RIBEIRO, R. R. Universidade, escola e ensino de história: as tramas da formação dos professores no Brasil. In: RODRIGUES, J. P.; JOANONI NETO, V. (Org.). Os 40 anos de Faire de l'histoire e a historiografia brasileira: IV Seminário Internacional de História e Historiografia (UFMT - 2015). Cuiabá: EdUFMT, 2016, p. 191-212.

${ }^{47}$ MATTOS, S. R. O Brasil em lições: a história como disciplina escolar em Joaquim Manuel de Macedo. Rio de Janeiro: Access, 2000.

${ }^{48}$ CEREZER, O. M. Diretrizes curriculares para o ensino de história e cultura afro-brasileira e indígena: implementação e impactos na formação, saberes e práticas de professores de história iniciantes (Mato Grosso, Brasil). Tese (Doutorado em Educação). Universidade Federal de Uberlândia. Uberlândia, 2015. 
${ }^{49}$ BARCA, Isabel. Ideias chave para a educação histórica: uma busca de (inter)identidades. História Revista. Goiânia, v. 17, n. 1, p. 37-51, jan./jun. 2012.

${ }^{50}$ AMADO, J. Região, Sertão, Nação. Estudos Históricos. Rio de Janeiro, v. 8, n.5, p. 145-151, 1995.

51 SALGUEIRO, M. M. Fugindo do estigma: visões sobre Mato Grosso nas páginas da Série Realidade Brasileira e da Revista Brasil-Oeste. Anos 90. Porto Alegre, v. 24, n. 46, p. 269-300, dez. 2017.

${ }^{52}$ BITTENCOURT, C. M. F. Capitalismo e cidadania nas atuais propostas curriculares de História. In: . $O$ saber histórico em sala de aula. 12. ed. São Paulo: Contexto, 2015, p. 11-27.

${ }^{53}$ BITTENCOURT, C. M. F. Capitalismo e cidadania nas atuais propostas curriculares de História. In: $O$ saber histórico em sala de aula. 12. ed. São Paulo: Contexto, 2015, p. 11-27.

${ }^{54}$ Citado por ABUD, K. M. Processos de construção do saber histórico escolar. História \& Ensino. Londrina, v. 11 , p. 25-34, 2005.

${ }^{55}$ PESAVENTO, S. J. Cotidiano da República. Porto Alegre: Ed. UFRGS, 1990.

${ }^{56}$ AMADO, J. Região, Sertão, Nação. Estudos Históricos. Rio de Janeiro, v. 8, n.5, 1995, p. 148-149.

${ }^{57}$ LIMA, M. Escrever nas aulas de história: aspectos da aprendizagem histórica em sociedade de cultura escrita. In: LEOPOLDINO, M. A.; LIMA, M. (Org.). Didática do Ensino de História: teorias, conceitos, práticas. Curitiba: Prismas, 2017, p. 105-129.

${ }^{58}$ ABUD, K. M. Conhecimento histórico e ensino de história: a produção de conhecimento histórico escolar. In: Encontros com a história, n. 2. Sujeito na história: práticas e representações. Bauru: Edusc, 2001.

${ }^{59}$ BENTIVLOGIO, P. D. J. Cultura política e historiografia alemã no século XIX: a Escola Histórica Prussiana e a Historische Zeitschrift. Revista Teoria da História. Goiânia, v, 3, n. 1, 20-58, 2014 Disponível em: https://www.revistas.ufg.br/teoria/article/view/28629. Acesso em: 20 jun. 2021.

${ }^{60}$ BURKE, P. Abertura: a nova história, seu passado e seu futuro. In: (Org.). A escrita da História: novas perspectivas. São Paulo: Editora UNESP, 1992. p. 7-38.

61 Introdução aos estudos de história e historiografia. Desafio da História. Disponível em: https://desafiodahistoria.wordpress.com/2011/02/03/introducao-ao-estudo-da-historia-e-historiografia/ Acesso em: 14 jan. 2020

${ }^{62}$ CANAVARros, O.; PERARO, M. A.; BORGES, F. T. M.; JOANONI NETO, V. Mato Grosso nos estudos historiográficos. Territórios \& Fronteiras. Cuiabá, v. 5, n. 2, p. 79-97, jan./jul. 2012.

\section{Referências}

ABUD, K. M. A guardiã das tradições: A História e seu código curricular. Educar. Curitiba, n. 42, p. 163-171, out./dez. 2011.

Conhecimento histórico e ensino de história: a produção de conhecimento histórico escolar. In: Encontros com a história, n. 2. Sujeito na história: práticas e representações. Bauru: Edusc, 2001.

Processos de construção do saber histórico escolar. História \& Ensino. Londrina, v. 11 , p. 25-34, 2005.

ALMEIDA, M. A. A Presença indígena em Vila Maria do Paraguai: os Bororo Cabaçal. In: CHAVES, O. R.; ARRUDA, E. F. (Org.). História e Memória Cáceres. Cáceres: Ed. Unemat, 2011. p. 35-49.

AMADO, J. História e região: reconhecendo e reconstruindo espaços. In: AMADO, J.; SILVA, M. A. (Coord.). República em migalhas: história regional e local. São Paulo: ANPUH; Marco Zero; CNPq, 1990, p. 1-19. 
BARCA, I. Ideias chave para a educação histórica: uma busca de (inter)identidades. História Revista. Goiânia, v. 17, n. 1, p. 37-51, jan./jun. 2012.

BENTIVOGLIO, P. D. J. Cultura política e historiografia alemã no século XIX: a Escola Histórica Prussiana e a Historische Zeitschrift. Revista de Teoria da História. Goiânia, v. 3, n. 1, p. 20-58, 2014. Disponível em: https://www.revistas.ufg.br/teoria/article/view/28629. Acesso em: 20 jun. 2021.

BITTENCOURT, C. M. F. Capitalismo e cidadania nas atuais propostas curriculares de História. In: . (Org.). O saber histórico em sala de aula. 12. ed. São Paulo: Contexto, 2015, p. 11-27.

BURKE, P. Abertura: a nova história, seu passado e seu futuro. In: (Org.). A escrita da História: novas perspectivas. São Paulo: Ed. Unesp, 1992. p. 7-38.

CANAVARROS, O.; PERARO, M. A.; BORGES, F. T. M. B.; JOANONI NETO, V. Mato Grosso nos estudos historiográficos. Territórios \& Fronteiras. Cuiabá, v. 5, n. 2, p. 79-97, jan./jul. 2012.

CEREZER, O. M. Diretrizes curriculares para o ensino de história e cultura afro-brasileira e indígena: implementação e impactos na formação, saberes e práticas de professores de história iniciantes (Mato Grosso, Brasil). Tese (Doutorado em Educação). Universidade Federal de Uberlândia. Uberlândia, 2015.

CASTRO, M. H. G.; TORRES, H. G.; FRANÇA, D. Os jovens e o gargalo do Ensino Médio brasileiro. São Paulo: Fundação Sistema Nacional de Análise de Dados, 2013. Disponível em: $\quad$ https://www.seade.gov.br/wpcontent/uploads/2014/06/Primeira_Analise_n5_agosto_2013.pdf. Acesso em: 20 jun. 2021.

CUNHA, A. V. C. Invenção do saber histórico escolar: apropriações das narrativas históricas escolares pela prática pedagógica dos professores de história. Dissertação (Mestrado em Educação). Universidade Federal de Pernambuco. Recife, 2005.

FARIA, P. C. J. Do campus universitário ao campus socialis: Em busca da universidade pública. Mulemba. Luanda, v. 6, n. 11, p. 317-324, 2016.

INTRODUÇÃO AOS ESTUDOS DE HISTÓRIA E HISTORIOGRAFIA. Desafio da História. Disponível em: https://desafiodahistoria.wordpress.com/2011/02/03/introducao-aoestudo-da-historia-e-historiografia/ Acesso em: 14 jan. 2020.

LACERDA, R. G. Instantâneo histórico de Cáceres. In: CHAVES, O. R. ARRUDA, E. F. (Org.). História e Memória Cáceres. Cáceres: Ed. Unemat, 2011, p. 193-215.

LE GOFF, Jacques. História e memória. Campinas: Ed. Unicamp, 1994.

LIMA, M. Escrever nas aulas de história: aspectos da aprendizagem histórica em sociedade de cultura escrita. In: LEOPOLDINO, M. A.; LIMA, M. (Org.). Didática do Ensino de História: teorias, conceitos, práticas. Curitiba: Prismas, 2017, p. 105-129.

MATTOS, S. R. O Brasil em lições: a história como disciplina escolar em Joaquim Manuel de Macedo. Rio de Janeiro: Access, 2000. 
MORENO, G.; HIGA, T. C. S. Geografia de Mato Grosso: território, sociedade, ambiente. 2. ed. revista. e atual. Cuiabá: Entrelinhas, 2017.

PESAVENTO, S. J. Cotidiano da República. Porto Alegre: Ed. UFRGS, 1990.

ROMANELLI, R. Imagens da colonização: a representação do índio de Caminha a Vieira. Rio de Janeiro: Zahar Ed., 1996.

RIBEIRO, R. R. Universidade, escola e ensino de história: as tramas da formação dos professores no Brasil. In: RODRIGUES, J. P.; JOANONI NETO, V. (Org.). Os 40 anos de Faire de l'histoire e a historiografia brasileira: IV Seminário Internacional de História e Historiografia (UFMT - 2015). Cuiabá: EdUFMT, 2016, p. 191-212.

ROCHA, E. O que é mito? São Paulo: Brasiliense, 1999. (Coleção primeiros passos 151).

SALGUEIRO, M. M. Fugindo do estigma: visões sobre Mato Grosso nas páginas da Série Realidade Brasileira e da Revista Brasil-Oeste. Anos 90. Porto Alegre, v. 24, n. 46, p. $269-$ 300, dez. 2017.

SILVA, S. M. A. Novas metodologias no ensino de História Local: a gincana cultural como estratégia didática para o Ensino de História no Piauí. Anais do XXVI Simpósio Nacional de História - ANPUH São Paulo, julho 2011. Disponível em: https://anpuh.org.br/index.php/documentos/anais/category-items/1-anais-simposios-anpuh/32snh26. Acesso em: 28 mai. 2021.

SIQUEIRA, E. M. História de Mato Grosso: da ancestralidade aos dias atuais. 2. ed. atual. e ampl. Cuiabá: Entrelinhas, 2017.

SOUZA, S. C. S. O que vocês sabem sobre história de Mato Grosso?: Ensino de História Regional e Local nos planos de ensino das escolas estaduais de Cáceres/MT. Dissertação (Mestrado em História). Universidade Federal de Mato Grosso. Cuiabá, 2019.

PINHO, R. T. Cáceres: Olhares sobre a tessitura urbana de São Luís de Cáceres. In: CHAVES, O. R.; ARRUDA, E. F. (Org.). História e Memória Cáceres. Ed. Unemat, 2011, p. 66-80.

ZABALZA, M. Diários de aula: um instrumento de pesquisa e desenvolvimento profissional. Porto Alegre: Artmed, 2004.

ZARBATO, J. A. M. Patrimônio, cultura e processos educativos em história: percursos e reflexões. Campo Grande: Life Editora, 2018. 